\title{
The introduction of practical exercises of rescuing a drowning person within the subject of basic clinic medicine and first aid for students of health sciences as a challenge for interdisciplinary cooperation
}

\author{
Damjan Slabe ${ }^{1 \mathrm{a}}$, Eva Dolenc ${ }^{1}$, Amalija Sazonov ${ }^{1}$, and Nina $\mathrm{Hiti}^{1}$ \\ ${ }^{1}$ University of Ljubljana, Faculty of Health Sciences, Zdravstvena pot 5, 1000 Ljubljana, Slovenia
}

\begin{abstract}
Drowning, being one of the most common causes of death is a public health problem. The concept of the drowning chain of survival puts great emphasis on providing security. Rescuing a drowning person in the stage of impaired judgement is a dangerous action. A rescuer can put at risk their own life at this stage. Health workers are potentially more exposed to this risk. In the field of education of health workers interdisciplinarity is one of the key concepts. Within the subject Basics of the Clinical Medicine and First Aid, we provided students the experience of saving a drowning person in a simulated exercise, thus trying to persuade them to choose safer strategies of rescuing. The subject of our research were students of health sciences. 506 students solved the questionnaire. After having performed a practical exercise of saving a drowning person, students choose less risky strategies of rescuing a person in the stage of impaired judgement. Students thus gain the experience of rescuing drowning people in more difficult circumstances and their awareness of the importance of security increases after the exercise, which helps to reduce the number of lives risked in accidents. Keywords: drowning, rescuing a drowning person, security
\end{abstract}

\section{Introduction}

The mission of health schools is to educate competent health workers who know and realize the meaning of preventive activities against the public health problems. Drowning is one of these problems, as being one of the most common causes of death on the world scale. Every hour of every day more than 40 people die because of drowning; every year there are more than 372000 deaths because of drowning [1]. The concept of the drowning chain of survival

${ }^{\text {a }}$ Corresponding author: damjan.slabe@zf.uni-lj.si 
describes five links that increase the survival rate. This model places great emphasis on ensuring the safety [2].

Health and sports educators in the role of health promoters represent key role in the first link in the chain of survival, because the latter refers to the preventive actions against the risk factors for drowning. Known factors are male gender, younger than 14 years of age, lower income and lower education levels. Among the most influential are the use of alcohol, other risk behaviour manners and health status (exp. epilepsy) [3,4]. Children up to 4 years old, mostly drown in swimming pools, with increasing age increases the percentage of drowning in open waters (rivers, lakes, sea). Accidents are the result of overestimation of their own abilities in rushing rivers, sudden weather changes and poor or no supervision over children [5]. As the most important risk factor for drowning as numerous studies indicated, was the absence of other persons (qualified paramedic or a layman) and swimming skills of the drowning [6,7]. The first link in the chain of survival "Prevent drowning- be safe in and around water" can be, as recommended by the World Health Organization [1], among other implements, with increased swimming capabilities that an individual must acquire as a child during school and in training bystanders in safety, rescue and resuscitation. In Slovenia, the Law on the Protection against Drowning [8] requires that primary and secondary schools in the context of education provide for all students the opportunity to learn to swim. Residents train to prevent drowning in other organized forms of training (for example students in the programmes of extracurricular activities).

In case when drowning occurs, it is necessary under article 2 of the drowning chain of survival to "call for help". The Law on the Protection against Drowning [8] in Slovenia stipulates that in the case of drowning everyone is obligated to assist in accordance with one's abilities. If one cannot help without endangering their own safety and the safety of others, one must immediately inform the nearest PSAP call (112) or the police. Once the rescuer "gets an appropriate flotation device", as dictated in the third step of the chain, he begins the actual "rescuing from water" (fourth step of the chain). Water rescue begins with an assessment of the condition of the drowning person, the circumstances and assessment and evaluation of their own swimming abilities [9].

Drowning most often begins when the drowning person is otherwise fully conscious, but only with difficulty adhering to the surface of the water. The fear of respiratory compromise is growing, so drowning person rises head above the water, and thus puts the body in an increasingly upright position. Bad swimmers in such a situation does not withstand long. Most often in one of the breaths, water crashes into the throat, triggering a reflex cough. The coughing expels air out of the lungs, this reduces the buoyancy of the body. In situation like drowning person is trying to get to a safe breathing with increased body movement, losses judgment and is in panic. Instinctively begins to fight for life. In this phase, he keeps breath and later swallows water. This drowning phase is called the agony. For emergency responders can the drowning person in this stage be extremely dangerous. He grips around him, and if he gets any anchoring, he is convulsively grasping to pull himself over a water surface [10]. The modern doctrine of rescue from the water in the world is to choose the safest route and it recommends indirect rescue when there is no contact between rescuers and drowning person and therefore no risk to drowning the rescuer in the phase of agony [9].

In case when a drowning person is at the stage of immobility, the rescuer should begin with personal direct rescue operations as soon as possible. Immobility phase occurs after a phase of agony when excessive concentration of $\mathrm{CO}_{2}$ in the blood leads to malfunction of the respiratory centre, and consequently greater quantity of water begins to penetrate into the lungs. A drowning person at this stage is most often submerged. This phase does not last long, when oxygen concentration in blood is below a certain level, they passes out and sinks to the bottom [10]. Even with a personal direct rescue operation, rescuer should first 
ensure their own safety. Drowning person is no dangerous for the rescuer, but there must be other factors taken into account, such as water (depth, eddies, current, waves). Even with excellent swimming skills, a rescuer can be helpless against water and weather conditions [11]. Self-perceived knowledge of the eyewitness rescuer can be questioned. The last link in the drowning chain of survival is an appropriate aid, when the drowning person is saved from the water. Algorithms of giving first aid to an injured or a suddenly sick person begins with safety concerns [2].

To effectively achieve the objective of the drowning chain of survival and to improve the survival of the drowning person, it is important to link together professionals from different fields. In such a wide field of health protection covered by the first link in the chain, the preventive actions of an interdisciplinary team of health and sports-teaching staff is more effective. Also (regarding the second link in the chain), it is very important to promote timely emergency call in case of an accident. 112 is the uniform European number for emergency, adopted by a decision of the Council of the European Union in 1991. Approximately $90 \%$ of Slovenians know this number to call it in the area of Slovenia, less - about $44 \%$, know it as a uniform European number [12]. Advantages of interdisciplinary education of the general population and health professionals is highly expressed in the case when drowning occurs and it is necessary to administer first aid to a drowning person. Life of a rescuer could be quickly compromised due to hasty reactions. Health workers are even more liable to this risk due to the legal and ethical responsibilities. In our case, we gave our students who wanted to obtain the title of health care worker, the practical experience of rescuing of drowning person and thus influenced them to opt for safer water rescue strategies. We have established that health care workers who have pursued a professional exam, in most cases, when theoretically rescuing a drowning person, are opting for risky rescue approaches. At the Faculty of Health Sciences at the University of Ljubljana students of first aid have been performing a practical exercise of rescuing a drowning person ever since the school year 2006/2007. Exercises are included in the framework of the course Fundamentals of clinical medicine and first aid on first and second year. It is part of the curriculum of undergraduate studies for eight courses Faculty of Health Sciences: midwifery, occupational therapy, physiotherapy, laboratory dental prosthetics, orthotics and prosthetics, radiological technology, sanitary engineering and nursing. Students of the Faculty of Pharmacy in University of Ljubljana have these topics included in the framework of practical training all Bologna reformed study programme. The exercise consists of two teaching hours and takes place in and by a pool. The short theoretical introduction follows by practical part, which includes rescuing from the shore with the ring, life-saving jump in the water, helping the disabled swimmer, rescuing drowning person in agony with indirect rescue, rescue of unconscious and submerged drowning person. The basic resuscitation procedures are introduced to students in lectures and tutorials in first aid cabinet. To carry out interdisciplinary work is one of the key concepts. The Group consists of a lecturer with the title of professor of physical education, professor of health education, a registered nurse with a master's degree in nursing and a nurse with additional education graduate organizer.

\section{Purpose}

To present the importance of practical exercises in saving a drowning person within the subject Basics of the Clinical Medicine and First Aid as an example of interdisciplinary cooperation in education of health sciences students. To determine the influence of practical exercises on the choice of the rescuing strategy in the stage of immobility.

To determine whether those students who are already attending water rescue practice and self-evaluated themselves as strong swimmers, opt for safer ways of rescuing a 
drowning person in agony phase, compared to those students who have not yet attended exercises in water rescue. We set the main hypothesis that students who attended water rescue and are more confident swimmers (and also potentially at greater risk), opt for safer ways of rescuing a drowning person in the theoretical case of drowning in the phase of agony, compared with those who have not yet participated in the water rescue exercises. We wanted to determine how students understood the concept of ensuring the safety when rescuing a drowning person in accordance to the concept of the five links in the drowning chain of survival. It also aims to identify how students perceive water rescue practice as a compulsory part of the course Fundamentals of clinical medicine and first aid.

\section{Method}

Data collection took place in the context of descriptive research methods according to the preceding literature review, with the help of an anonymous online questionnaire in the period from January to March 2015. The questions were open-ended and closed. Object of the research were students of Faculty of Health Sciences and the Faculty of Pharmacy, University of Ljubljana, which have, in a study programme in the context of exercises of first aid, a compulsory practice water rescue. Participation was voluntary and anonymous and has any impact on the evaluation of the study obligations.

The sample included 506 students. Less than half of respondents (49\%) answered the questionnaire before the exercises of first aid and water rescue, the rest $(51 \%)$ answered the questionnaire after attending the exercises of first aid and water rescue. Derived quantitative data were processed with statistical data processing IBM SPSS Statistics 24. The results of the study were compared with the results of other studies in Slovenia and abroad. The $\chi 2$ test was used to determine statistical significance of differences in proportions. The limit for a statistically significant difference was set at $\mathrm{p}<0.05$. The actual assessment of swimming ability was made on the basis of the swim test done during water rescue exercises. There were 114 students observed from the different courses.

\section{Results}

The survey covered 506 people. The largest proportion of respondents were women ( $83 \%)$, the majority of respondents ( $71 \%$ ) falls within the age limits from 21 to 25 years (figure 1).

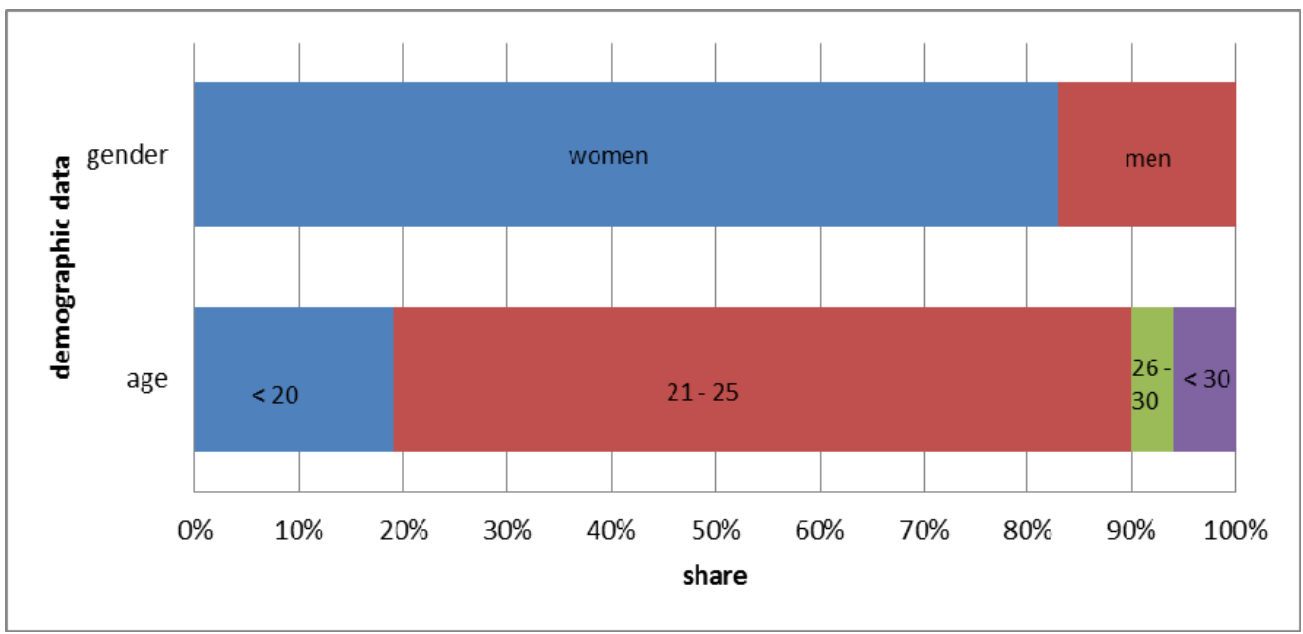

Fig. 1. Demographics of respondents. 
Most respondents in the light of their own (subjective) criteria learned how to swim when they were between 4 and 8.5 years old (average age was 6 years). The average grade of all the self-assessment swimming skills of surveyed students is 3.5 (table 1). $25.4 \%$ of all tested students $(n=114)$ successfully dives and swims under water at least 5 meters, while watching the water without aids and without holding their nose. These are the students who have successfully passed the test of swimming ability and self-evaluated their swimming abilities with the rating of 4 (on the scale from 1 to 5).

Table 1. Information on self- evaluation of swimming ability.

\begin{tabular}{cccccccc}
\hline $\begin{array}{c}\text { self- } \\
\text { assessment } \\
\text { swimming } \\
\text { skills }\end{array}$ & $\begin{array}{c}\text { insufficient } \\
\text { (1) }\end{array}$ & $\begin{array}{c}\text { sufficient } \\
\text { (2) }\end{array}$ & $\begin{array}{c}\text { good } \\
\mathbf{( 3 )}\end{array}$ & $\begin{array}{c}\text { very } \\
\text { good } \\
\mathbf{( 4 )}\end{array}$ & $\begin{array}{c}\text { excellent } \\
\mathbf{( 5 )}\end{array}$ & average & $\begin{array}{c}\text { standard } \\
\text { deviation }\end{array}$ \\
\hline $\begin{array}{c}\text { percentage } \\
\text { of answers } \\
\text { of } \\
\text { respondent }\end{array}$ & $1 \%$ & $13 \%$ & $32 \%$ & $42 \%$ & $13 \%$ & 3.5 & 0.9 \\
\hline
\end{tabular}

$85 \%$ of respondents believe that the water rescue may compromise lives of the rescuers (figure 2).

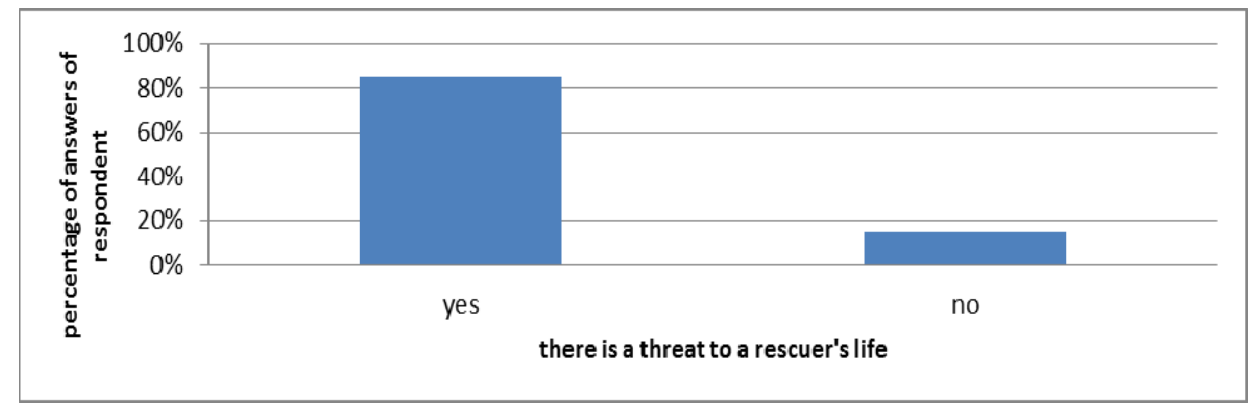

Fig.2. The percentage distribution of respondents' answers to the question about the safety of the rescuer in rescuing the drowning person.

$19 \%$ of surveyed health care workers think that they are obliged to save the drowning person, even at the cost of their own lives (figure 3).

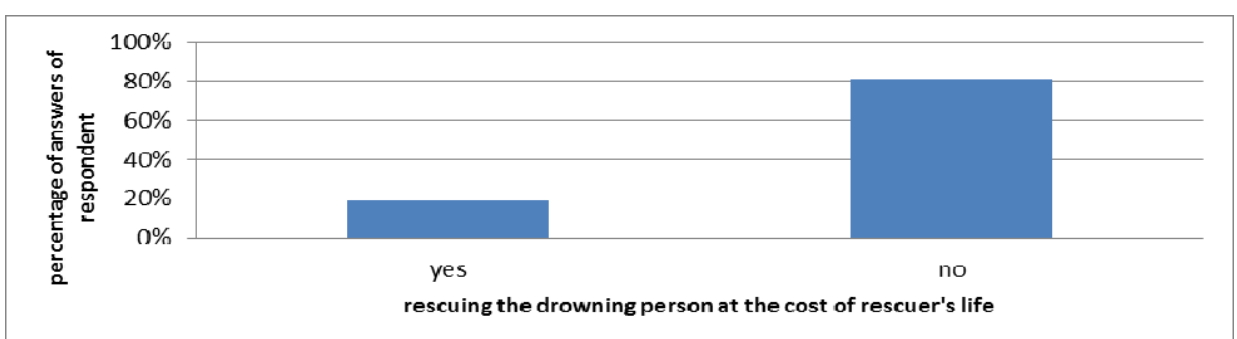

Fig. 2. Percentage distribution of respondents' answers in relation to the agreement with the statement that health professionals are obliged to save the drowning person at the cost of their own life.

The biggest threat to the safety of rescuers according to the interviewed are drowning persons, environmental factors (weather and terrain) and rescuer features (table 2). 
Table 2. The frequency distribution of answers of respondents to the question about the possible dangers in the water rescue.

\begin{tabular}{llc}
\hline \multicolumn{1}{c}{ danger } & \multicolumn{1}{c}{ description } & Frequency (n= 506) \\
\hline drowning person & $\begin{array}{l}\text { can drown or injure rescuer because of the } \\
\text { agony phase (panic, increased body } \\
\text { movements, fear), weight, gender (male) }\end{array}$ & \\
environmental factors & $\begin{array}{l}\text { water, deep water, cold water, waves, } \\
\text { current, flowing river, sea, strong current, } \\
\text { rocks, floating objects, storm, cliff, distance } \\
\text { from the coast, animals, boats }\end{array}$ & \\
overestimation of abilities, ignorance of \\
rescuer & $\begin{array}{l}\text { rescue techniques, physical defects (fitness, } \\
\text { weight), inexperience, poor swimming } \\
\text { ability, failure to comply with rules ... }\end{array}$ & \\
\hline
\end{tabular}

In the theoretical case of swimming accident, respondents answered very differently to the question of how to act, if at a distance of approximately 25 meters they see a person in the water with a frantic effort to hold on to the water level and occasionally disappears below the surface (figure 4).

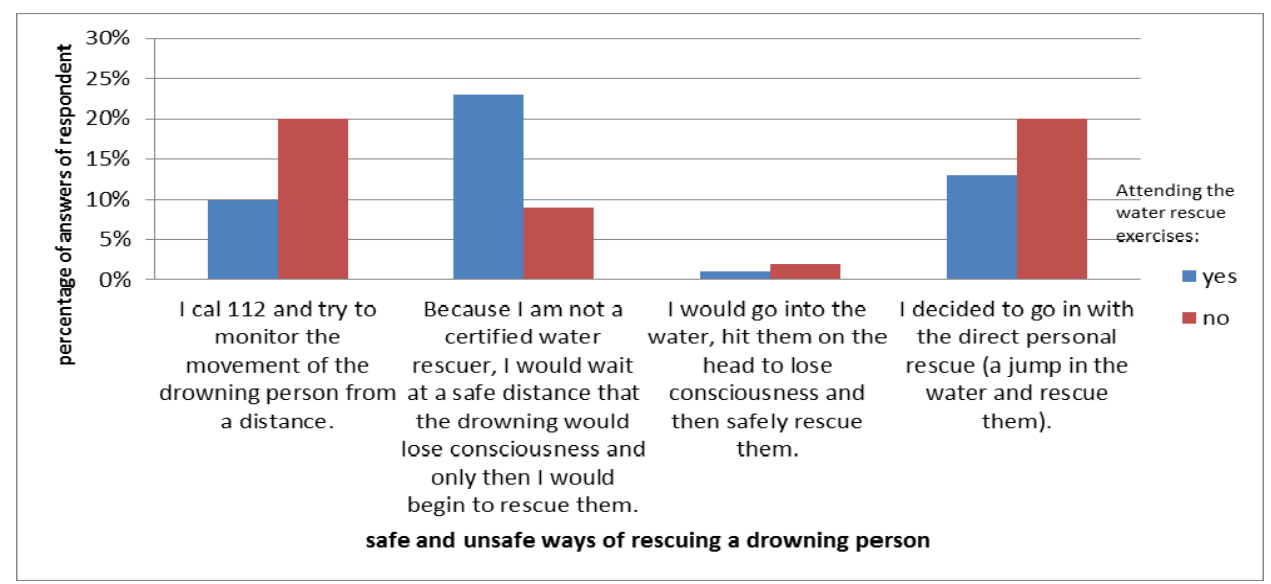

Fig. 3. Comparison of the respondents' answers according to attendance of water rescue exercises to a question about rescuing a drowning person in the agony phase from a 25 meters distance.

Results of the $\chi^{2}$ test $(\mathrm{p}<0.05)$ confirm the hypothesis that students who are more confident swimmers (self-assessment swimming skills 4 or 5 on the scale from 1 to 5 under- excellent) opt for safer ways of rescuing from the water in the theoretical case of drowning in agony stage after attending water rescue exercise compared to those who have not yet participated water rescue exercise (Table 3). Those students who have self-assessed themselves as inferior swimmers (self-assessment swimming skills 1, 2 or 3 on the scale school ratings from 1 to 5-under-excellent), before and after the exercises opt for safer ways of water rescue. 
Table 3. Choice comparison of safe and unsafe methods of water rescue between different groups of respondents.

\begin{tabular}{|c|c|c|}
\hline \multicolumn{3}{|c|}{ self-assessment - bad swimmers $(46 \%)$} \\
\hline $\begin{array}{c}\text { attended water rescue } \\
\text { exercise }\end{array}$ & safe water rescue ways & $\begin{array}{c}\text { unsafe water rescue } \\
\text { ways }\end{array}$ \\
\hline yes & $31 \% \#$ & $12 \%$ \\
\hline no & $36 \%$ & $19 \%$ \\
\hline all (n) & 154 & 76 \\
\hline \multicolumn{3}{|c|}{ self-assessment - good swimmers (54\%) } \\
\hline yes & $34 \%$ * & $20 \%$ \\
\hline no & $22 \%$ & $24 \%$ \\
\hline
\end{tabular}

\# There are no statistically significant differences between the two groups before and after lab work and selection of a water rescue method.

* Statistically significant $(\mathrm{p}<0.05)$ higher than in the group who has not yet performed exercises in water rescue.

More than $80 \%$ of respondents think that water rescue exercises and how to give first aid to a drowning person is an important and very much needed experience. They also indicated that it is an important experience, but the exercises are too short. (figure 5)

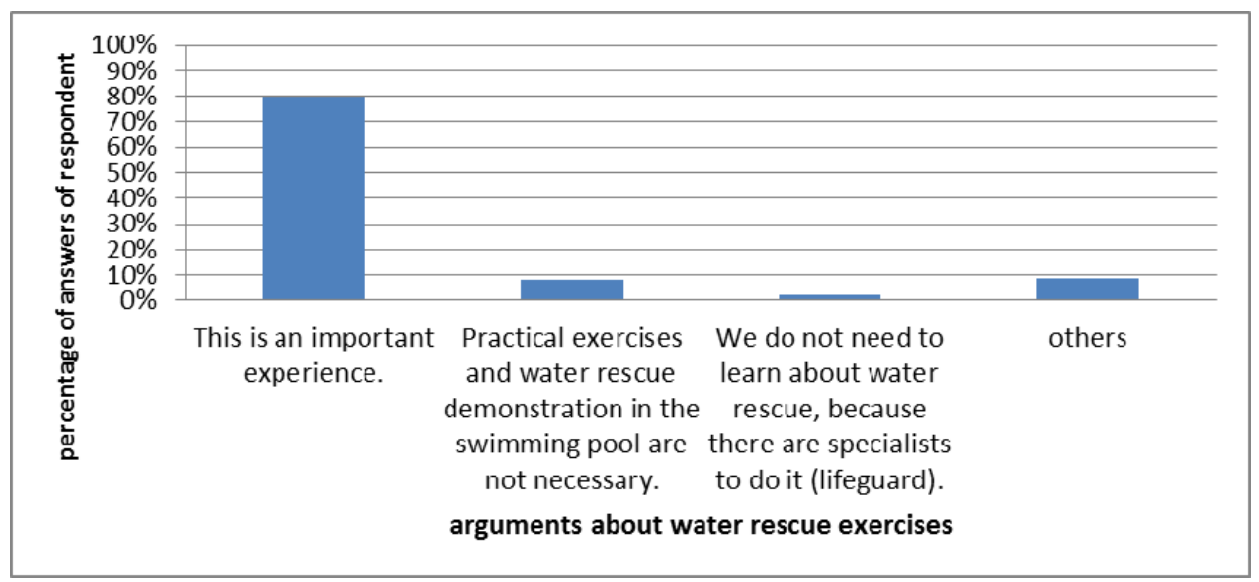

Fig. 4.: Distribution of shares of the respondents' answers to the question about the importance of water rescue exercises as a part of First aid exercises.

\section{Discussion and Conclusion}

Good swimming skills are one the most powerful preventive measure against drowning [13]. Students of medical direction, which were included in the study, self-evaluated themselves as strong swimmers; the average of all the self-assessment swimming skills of students surveyed is 3.5. More than half - $54 \%$ of respondents felt that they swim very good or excellent. We have found that there is a gap between self-perception of own swimming ability and actual knowledge of swimming. Only $25 \%$ of all tested students $(\mathrm{n}=$ 114) successfully dives and swims under the water at least 5 meters, while watching the water without aids and without pressing their nose. It has been recommended by the World Congress on Drowning and the American Academy of Pediatrics, that all people, after their fourth birthday, should know drowning survival skills, familiarize themselves with safety around the water, and learn basic swimming skills [14]. Considering that more and more 
drownings occur in nature, one should be able to control his body in the water in circumstances that are not ideal (a sudden drop in the water, strong current, high waves, violent immersion) and try to learn to swim under the relevant control, because also the excellent swimming skills could sometimes leave a man defenceless against the water [11]. In the event when students find themselves in the role of the lifeguard, too high self-esteem and too good self-evaluation about their swimming skills can be a big trap. The aim of a safe swimmer is not the complete knowledge of swimming, but knowledge good enough to allow him to learn freely and safely about the aquatic environment aware of their swimming limitations [15]. Given to the nature of the work they perform health workers have already expressed a higher degree of desire to help, besides being obliged to the ethical and legal responsibility. With more confidence about swimming skills and a desire to help fellow human beings, in the event of an accident with a drowning person, they can forget their own safety. Highly unfavourable complication in any rescue action is in fact hurt or even dead rescuer. $85 \%$ of respondents acknowledging that in water rescue the rescuer's life may also be in danger. Most respondents $(81 \%)$ rightly considers that health professionals are not obliged to save the drowning on the price risking their own lives, but $19 \%$ of them mistakenly believe that it is their the duty to save the drowning person, notwithstanding such a risk. In cases where the situation is dangerous and the rescuer does not have adequate tools to deal with the situation from the land they call 112 and wait for the arrival of the relevant emergency services, may be the only sensible choice.

Rescuing a drowning from the water is a complex process, which begins with the assessment, which includes an assessment of their own knowledge of swimming and rescue ability, assessment of the circumstances (water, weather conditions) and the state of the drowning person [9]. Water and weather conditions can make rescuing very difficult or even impossible. Assessment of the state of the drowning person requires the acquisition and evaluation of data, such as the duration of drowning, water temperature and condition of drowning person [16]. The biggest threat to the safety of rescuers, according to the respondents are drowning person, environmental factors (weather and terrain) and skills of the rescuer. Respondents highlighted higher weight of the drowning person as a possible obstacle to the rescue. When a drowning person is in the phase of impaired judgment, he can disable the rescuer swimming and even drown him [17]. This danger have emphasized a number of respondents (314). Whoever is not physical strong and does not know the correct approaches and methods of water rescue should only begin rescuing when drowning person is tired or when agony phase enters a phase of immobility [5].

In the theoretical case of swimming accident respondents answered very differently to the question of how to rescue the person in the phase of agony. Among the safe rescue methods we included calling 112 and tracking and locating drowning person, waiting at a safe distance until drowning person in agony phase lose unconscious and then water rescue. Unsafe rescue methods would be jumping into the water or a direct personal rescue in a way that the rescuer first hit drowning person in the phase of agony on the head to pass out, and then safely rescue him, which is inappropriate. Results $\chi^{2}$ test $(\mathrm{p}<0.05)$ showed that those students who indicate their swimming skills as bad (by school grades estimates insufficient 1,2 adequate or mediocre 3 ) are more likely to opt for the safe rescue methods before and after participation to water rescue exercise in the context of the study obligations. We estimate that there is a higher risk among those respondents who rated their swimming skills as good (very good 4 or 5 excellent), as before performing water rescue exercises, they were more likely to opt for the more dangerous ways of water rescue. $\chi 2$ test results confirm the hypothesis that students who are more confident swimmers opt for safer ways of the water rescue in the theoretical case of drowning in agony stage after attending water rescue exercise, compared with those have not yet attended. The result confirms the importance of water rescue exercises in order to ensure the safety of the rescuer and 
drowning person in the concept of the drowning chain of survival to improve the survival of the drowning [2], which is amongst health workers even more important.

In order to help adequately a drowning person it is essentially to know the particularities of water rescue and first aid protocols that identify numerous authors of the research on the subject matter [6,7]. Comparison of knowledge of the prevention of drowning, knowledge of survival skills, understanding the process of drowning before and after training of various target groups showed, that the training participants are much more aware of the importance of safety concerns in the water before, during and after the drowning [18]. This is particularly true for health care workers, whose nature of work requires the adoption and strengthening of practical skills of water rescue and first aid to a drowning person. The students who attended water rescue exercises and first aid have better theoretical knowledge of the issue discussed then those who did not yet participate. Positive experience, which we introduced at the Medical Faculty of the University of Ljubljana, is an incentive for creators of study programmes for health professionals. Like the authors of related research, we can conclude that it is reasonable to include water rescue exercises in the context of first aid education, especially in educational programmes for health professionals, first providers and other target groups. They are more likely to meet with the drowning person and because of the strong desire to help, are more likely to overestimate their rescue abilities. Design and quality performance of such work requires the participation of experts in various fields. Participants are not expected to be capable of water rescue as licensed lifeguards. As healthcare professionals, they can gain experience that the water rescue has been already a complex action under favourable conditions. After the completion of exercise, their awareness of the importance of safety concerns increased which contributed to the fact that no more lives have been endangered in the disaster. The need for such work also supports the opinion of participants: that the water rescue and first aid to the drowning person is a necessary experience believes the majority of respondents.

\section{References}

1. World Health Organization. Global report in drowning. Preventing a leading killer. Geneva: WHO Press. (2014)

2. European Resusciation Council. Resuscitation 95, 1-80. European Resuscitation Council Guidelines for Resuscitation 2015 Section 1. Executive summary. (2015)

3. TJ. Flood. Water-Related Incidents in Maricopa Country, Arizona 2006. (2006)

4. TR. Driscoll, JA. Harrison, M. Steenkamp. 6., 10 (2), 107-113. (2004)

5. M. Kolar. Reševanje iz vode. In: Prva pomoč: priročnik s praktičnimi primeri, 599613. (2006)

6. D. Szpilman, J.L.M. Bierens Joost, J. Handley Anthony et al.. NEJM, 366, 2102-10. (2012)

7. J. Weiss. Pediatrics, 126 (1), 253-261. (2010)

8. Law on the Protection against Drowning. Uradni list RS, št. 42/07, Ljubljana. Accessed via: http://pisrs.si/Pis.web/pregledPredpisa?id=ZAKO2067\#<15.6.2016>

9. V. Kapus, H. Možina. Proces utapljanja. In: Reševanje iz vode, aktivna varnost in prva pomoč, 44-7. (2004)

10. I. Šink. Utopitve. In: Nesreče in varstvo pred njimi, 426-430. 2002

11. B. Pistotnik. Prosto potapljanje. Dejavnik motivacije in zanesljivosti plavalcev. V: 1.slovenski posvet o učenju plavanja in varnosti pred utapljanjem. (1994)

12. D. Slabe, M. Medja. Ujma 9 (23), 170. (2009)

13. The International Life Saving Federation. Drowning prevention strategies. A framework to reduce drowning deaths in the aquatic environment for nations/regions 
engaged in lifesaving. Belgium. Accessed via: http://www.ilsf.org/sites/ilsf.org/files/filefield/20151028_FINAL_Drowning_Preventio n_Strategies_ILS_Board_V01.pdf (2015)

14. L.M. Cortes, S.W. Hargarten, H.M. Hennes. Journal of Travel Medicine, 13 (1), 21-34. (2006)

15. V. Kapus, B. Štrumbelj, J. Kapus in sod.. Plavanje, učenje. Slovenska šola plavanja za novo tisočletje: učbenik za učence-študente, učitelje-profesorje, trenerje in starše. (2002)

16. R.D. Stewart, J.E. Campbell. Initial Airway Management. In: Basic Trauma Life Support for paramedics and other advanced providers. 60-1. (2004)

17. C. Ivšek. Reševanje iz vode Priročnik. (2008)

18. L. Quan, E. Bennet, CM. Branche. Interventions to prevent drowning. In: LS., Doll, SE., Bonzo, DA., Sleet et al., (eds), Handbook of injury and violence prevention, 8196. (2007) 